\title{
Human immunodeficiency virus type-1 subtypes of infected patients in Espírito Santo, Brazil
}

\author{
Valéria P Cabral, Carla B Cunha, Eneida FL Magalhaes, Lauro F Pinto-Neto*, \\ José Carlos Couto-Fernandez**, Reynaldo Dietze, Mariza G Morgado**, \\ Rodrigo Ribeiro-Rodrigues/ ${ }^{+}$
}

\begin{abstract}
Laboratório de Imunologia Celular e Molecular, Núcleo de Doenças Infecciosas, Universidade Federal do Espírito Santo, Av. Marechal Campos 1468, 29040-091 Vitória, ES, Brasil *Santa Casa de Misericórdia de Vitória, Vitória, ES, Brasil

**Laboratório de AIDS \& Imunologia Molecular, IOC-Fiocruz, Rio de Janeiro, RJ, Brasil
\end{abstract}

Genetic variability of human immunodeficiency virus type $=1$ (HIV-1) is a potential threat for both diagnosis and treatment of HIV/AIDS, as well as the development of effective vaccines. Up to now, HIV subtypes circulating among HIV-positive patients in the state of Espirito Santo were not known. In the present study, blood samples from 100 therapy-naïve HIV-1 infected patients were collected and the HIV subtype was determined through the Heteroduplex Mobility Assay (HMA). Ninety-seven out of 100 studied samples were subtyped by HMA, 73 samples (75.2\%) were from subtype B, 9 (9.3\%) from subtype F, 3 (3.1\%) from subtype C, $6(6.2 \%)$ Benv/Fgag, and another $6(6.2 \%)$ Fenv/Bgag, what suggests that recombinant viruses were present in the studied samples. Twenty-eight percent of the subtype B samples were represented by the Brazilian B" subtype, which were identified by RFLP with Fok I. Data presented here demonstrate that the epidemiological characteristics of the HIV epidemic in the state of Espirito Santo are similar to those from the other Southeastern states and helped to better understand the genetic polymorphism of HIV in Brazil.

Key words: human immunodeficiency virus type 1 (HIV-1) - subtype - Espírito Santo - Brazil

Human immunodeficiency virus (HIV) is characterized by a high degree of genetic variability, which is due to the high error rate of reverse transcriptase enzyme, the fast turn-over of virions in HIV-infected individuals, the possibility of recombination and changes in viral fitness (Cornelissen et al. 1996).

HIV-1 is clustered into three genetic groups: major $(\mathrm{M})$, outlier $(\mathrm{O})$, and non-major-non-outlier $(\mathrm{N})$. At least 9 circulating genetic subtypes (A-D, F-H, J, K) and at least 16 circulating recombinant forms (CRFs), namely CRF01-CRF16, have been identified so far within group M, which accounts for more than $90 \%$ of reported HIV/ AIDS cases (Vidal et al. 2000, Join United Nations Program on HIV/AIDS 2005). This broad genetic variability has implications for testing, treatment and vaccine development (Moore et al. 2001). Although it has also been hypothesized that distinct subtypes or CRFs may present differences in transmission efficiency and pathogenesis, no consistent evidence has been published to date (van Harmelen et al. 1997, Hu et al. 1999). Even though previous data suggest that all HIV subtypes display a similar sensitivity to antiretroviral drugs, viruses from certain subtypes or geographical regions may occasionally develop resistance to antiretroviral drugs faster than other viral variants (Wainberg 2004).

Financial partial support: Facitec

${ }^{+}$Corresponding author: rodrigrr@ndi.ufes.br

Received 13 June 2006

Accepted 1 November 2006
The heteroduplex mobility assay (HMA) has been widely used in Brazil for monitoring subtype distribution. Considering that inter-subtype recombination is an important source of HIV-1 genetic variation, subtype identification using the HMA based on both env and gag genes proved to be a useful tool (Heyndrickx et al. 2000). Identification of HIV subtypes through a constant surveillance is a potent epidemiological tool for monitoring the fast expansion of the HIV pandemic.

In Brazil the great majority of HIV isolates are identified as viruses belonging to subtype B. Recently however, the number of non-B and recombinant HIV isolates reported increased significantly (reviewed by Morgado et al. 2002). Most studies conducted in Brazil to evaluate the HIV diversity have been carried out using samples from the Southeastern region, mainly from the states of Rio de Janeiro and São Paulo. In contrast, there is so far no information regarding HIV subtypes circulation in Espírito Santo, another Brazilian Southeastern state, even though 5332 AIDS cases have been reported in this area between 1980 and 2005 (Ministério da Saúde 2005). The city of Vitória, the state capital, has an intense harbor activity, with dozens of ships from different parts of the world docking everyday, creating a favorable condition for the introduction of HIV-1 subtypes and CRFs. In the present study, we evaluated HIV-1 genetic diversity from Espírito Santo in infected individuals using HMA for env and gag genes.

\section{MATERIALS AND METHODS}

Study population - One hundred HIV-1 positive patients attending the HIV/AIDS outpatient clinic at Santa Casa de Misericórdia de Vitória, Espírito Santo, Brazil, were invited to participate in the current study. This study 
was submitted and approved by the Ethical Committee at Santa Casa de Misericórdia de Vitória, Espírito Santo, prior to patient enrollment. After signing an informed consent, patients had $5 \mathrm{ml}$ of blood drawn by venipuncture in sterile EDTA $\mathrm{K}_{3}$ treated blood collection tubes (Vacuntainer, Becton-Dickinson, CA, US). $\mathrm{CD}^{+} \mathrm{T}$ cell counts were determined by flow cytometry (Facscount, Becton-Dickinson) as described by the manufacturer at the Laboratório Central de Saúde Pública (Lacen-ES). Blood samples were sent to the Cellular and Molecular Immunology Laboratory, Núcleo de Doenças Infecciosas, Universidade Federal do Espírito Santo, within 4 $\mathrm{h}$ of collection for viral load determination and DNA extraction.

DNA extraction - Proviral DNA was isolated from peripheral blood samples (buffy coat) using the QIAmp ${ }^{\circledR}$ DNA Mini Kit (QIAGEN, Valencia, US) following the manufacturer's instructions provided with the kit. Purified DNA was aliquoted and stored at $-20^{\circ} \mathrm{C}$ until use.

Polymerase chain reaction (PCR) amplification of HIV env and gag sequences - Proviral DNA samples were amplified using a nested-PCR protocol as described elsewhere (Delwart et al. 1993, Heyndrickx et al. 2000).

HMA - The HMA technique was used to identify the HIV subtype present in DNA samples isolated from patients' buffy coats. PCR conditions and HMA subtyping were performed as previously described (Delwart at al. 1993, Heyndrickx et al. 2000). Plasmids containing the subtype reference sequences were provided by the NIH's AIDS Research and Reference Reagent Program.

Restriction fragment length polymorphism (RFLP) determination to identify $B$ " subtypes - RFLP to identify B" subtypes among B subtype-positive samples for the env gene followed described techniques (Morgado et al. 1998a, Covas et al. 1998).

Statistical analysis - The $\chi^{2}$ test was used to evaluate the relationship between HIV-1 subtype genetic variants and demographic and clinical variables such as gender, clinical status and $\mathrm{CD} 4^{+} \mathrm{T}$ cell counts. These analyses were performed using Epi Info 2000, version 1.0 for Windows, and results with $\mathrm{p}<0.05$ were considered statistically significant. We also used $95 \%$ confidence intervals (calculated using the exact binomial method) to determine the consistency of our study population with patients in the state AIDS database. These analyses were performed using STATA version 9.0 (STATA Corporation, College Station, TX, US).

\section{RESULTS}

HIV-1 subtype identification - HIV-1 subtype identification was accomplished in 97 (97\%) blood samples from HIV-1 positive patients. In the studied population, subtypes $\mathrm{B}, \mathrm{C}$, and $\mathrm{F}$ and recombinant $\mathrm{B} / \mathrm{F}$ HIV isolates were identified (Figure). Subtype B was the most prevalent subtype identified in 73 out of 97 samples $(75.3 \%$, 95\%CI: 66.7-83.8). Twenty-four out of 97 (24.7\%) samples cor-responded to non-B and recombinant virus as follows: subtype F $(9.3 \%, 95 \% \mathrm{CI}: 3.5-15.0)$, subtype
C (3.1\%, 95\%CI: 0-6.5), and recombinant B/F subtypes (12.4\%). Two distinct $\mathrm{B} / \mathrm{F}$ recombinant genomes were identified among the HIV-1 isolates that were grouped as Benv/Fgag (6.2\%, 95\%CI: 1.4-11.0) and Fenv/Bgag (6.2\%, 95\% CI: 1.4-11.0) subtypes. The identification of the Brazilian subtype B variant, known as subtype B", was achieved by Fok I RFLP assay. Twenty-two (27.8\%) out of 79 subtype Benv HIV isolates were identified as Brazilian subtype B" (data not shown).

Correlation between HIV-1 subtype and demographic or clinical variables - Socio-demographic, clinical and laboratorial data are summarized in the Table. No significant association between a given HIV-1 subtype and demographic or clinical variables was encountered in the studied population.

\section{DISCUSSION}

Although the HIV genetic diversity is well documented for the states of São Paulo and Rio de Janeiro, data for the remaining Southeastern states (Minas Gerais and Espírito Santo) are either incomplete or based on small sample sizes. To our knowledge, this is the first study designed to evaluate the genetic diversity of HIV isolates in Espírito Santo. HIV-1 subtypes B, F, and C as well as $\mathrm{B} / \mathrm{F}$ recombinant genomes were identified by HMA and their frequency was determined. Subtype B (75.3\%) was the most prevalent subtype followed by subtype F $(9.3 \%)$ and subtype C (3.1\%). Recombinance between $\mathrm{B} / \mathrm{F}$ subtypes represented $12.4 \%$ of all isolates tested. Despite the fact that the state of Espírito Santo has three important harbors (Vitória, Tubarão, and Capuaba), with an intense shipping activity, which could facilitate the introduction of new HIV subtypes from other regions of the world, data presented here show that the observed subtype distribution was similar to those previously reported for other Southeastern states (Rio de Janeiro and São Paulo), with a predominance of the B subtype (Morgado et al. 2002). Subtype B is the most prevalent subtype in the Southeastern, Northeastern and Central-Western part of Brazil (Morgado et al. 1998b, Stefani et al. 2000, Gadelha et al. 2003).

Different patterns of HIV-1 subtype distribution are frequently observed in Brazil, varying according to the geographical region (Morgado et al. 2002). In the present work, HIV-1 subtype C isolates were found in 3\% of studied samples, what concurs with literature data for other Southeastern states (Brazilian Network for HIV Isolation and Characterization 2000). This finding also agrees with the hypothesis that subtype $\mathrm{C}$ has been disseminated in the country following a South-North gradient pattern.

Interestingly, although reported previously in Rio de Janeiro (Janini et al. 1996, Couto-Fernandez et al. 2006), subtype D was not identified in our study. Although the observed frequency of subtype F (9.3\%) in our study was similar to other Southeastern states' observations, CoutoFernandez et al. (2005) reported a lower frequency (4.9\%) of subtype F among samples from Rio de Janeiro HIV patients. It is known that most subtype $\mathrm{F}$ characterized 


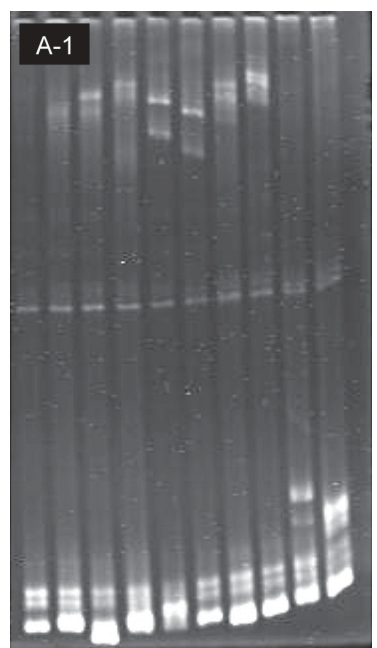

-- B1 B2 B3 C1 C2 D1 D2 F1 F2

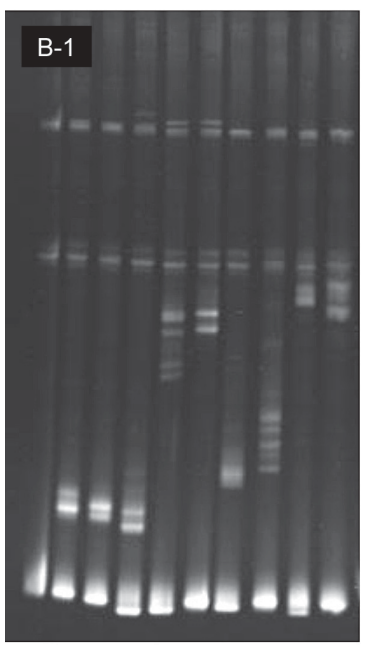

-- B1 B2 B3 C1 C2 D1 D2 F1 F2

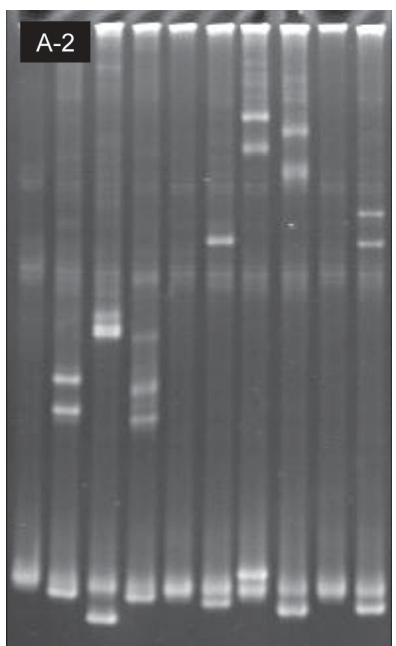

-- B1 B2 B3 C1 C2 D1 D2 F1 F2

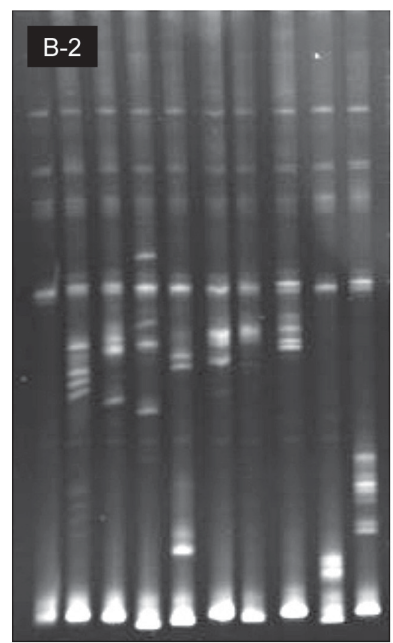

-- B1 B2 B3 C1 C2 D1 D2 F1 F2

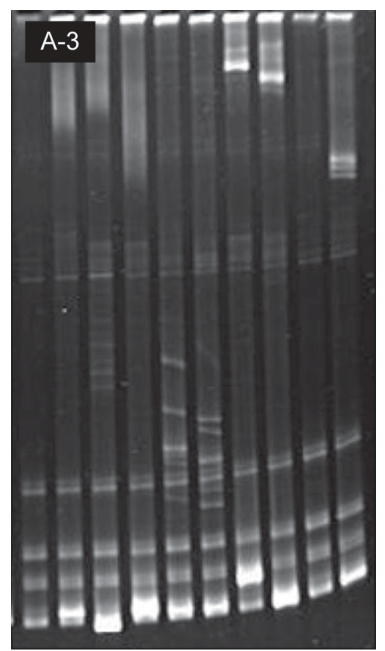

-- B1 B2 B3 C1 C2 D1 D2 F1 F2

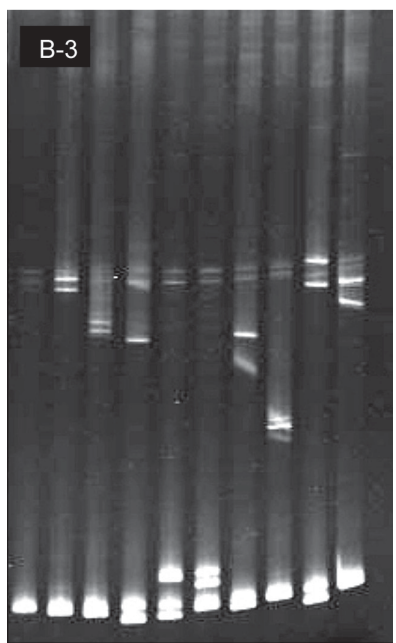

-- B1 B2 B3 C1 C2 D1 D2 F1 F2

Representative heteroduplex mobility assay (HMA) electrophoresis results from subtypes Fenv/Bgag (Figs A-1, B-1), Benv/Fgag (Figs A-2, B-2), and Cenv/Cgag (Figs A-3, B-3). HIV-1 env and gag genes are represented by the letters A and B, respectively. Samples from patients 30, 27 , and 47 are represented by the numbers 1,2 , and 3, respectively. The reference strains are indicated at the top of the gel. The env HMA was resolved by electrophoresis analysis at $200 \mathrm{~V}$ for $3 \mathrm{~h}$ on a $5 \%$ polyacrylamide gel in TBE buffer. The gag HMA was performed by electrophoresis analysis at 250 $\mathrm{V}$ for $2.5 \mathrm{~h}$ on a $5 \%$ polyacrylamide gel containing $20 \%$ urea in TBE buffer.

by either partial sequencing or HMA based only on the env gene turned out to be $\mathrm{B} / \mathrm{F}$ recombinant isolates when re-analyzed by either full sequencing or HMA on gag and $e n v$ genes, with the occurrence of a "pure" F subtype isolate being rare (Carr et al. 2001). Therefore, our results support previous findings showing that B and $\mathrm{F}$ (env/gag) recombinants are present at high frequencies within HIV-1 infected populations in different regions in Brazil (Guimarães et al. 2002).

We were neither able to confirm nor establish a significant correlation between the HIV-1 subtypes circulating in Espírito Santo with either clinical or epidemiological parameters. The lack of correlation between subtypes and clinical/epidemiological data has also been reported by other authors in Brazil (Guimarães et al. 2001, Turchi et al. 2002).
It has been estimated that $10 \%$ of all HIV isolates circulating in the world are recombinant virus (McCutchan et al. 2000). Indeed, we found that 12.4\% of all studied samples were from recombinant isolates from subtypes B and F (6.2\% Benv/Fgag and 6.2\% Fenv/ $\mathrm{Bgag})$. Although the HMA technique is accurate and suitable for subtype identification, these B and F samples should be considered only as potentially recombinants. For a sample to be regarded as a true recombinant, breakpoints between the studied regions need to be detected, what is achieved by nucleotide sequencing.

A subtype-B variant, known as the Brazilian subtype B (subtype B"), which differs from the traditional subtype $B$ by the presence of a sequence GWGR instead of the conserved sequence GPGR at the top of the V3 loop in the viral envelope, was identified in $27.8 \%$ of samples 
TABLE

Distribution of human immunodeficiency virus type-1 (HIV-1) env/gag subtype isolates according to demographic and clinical parameters of $100 \mathrm{HIV}-1$-infected individuals from the state of Espírito Santo, Brazil

\begin{tabular}{|c|c|c|c|c|c|c|c|}
\hline \multirow{3}{*}{ Characteristics } & \multicolumn{7}{|c|}{ HIV-1 env/gag subtypes } \\
\hline & Patients & $\mathrm{B} / \mathrm{B}$ & $\mathrm{F} / \mathrm{F}$ & $\mathrm{C} / \mathrm{C}$ & $\mathrm{B} / \mathrm{F}$ & $\mathrm{F} / \mathrm{B}$ & $\mathrm{ND}$ \\
\hline & $\mathrm{N}$ & 73 & 9 & 3 & 6 & 6 & 3 \\
\hline \multicolumn{8}{|l|}{ Gender } \\
\hline Male & 52 & 40 & 4 & - & 3 & 4 & 1 \\
\hline Female & 48 & 33 & 5 & 3 & 3 & 2 & 2 \\
\hline \multicolumn{8}{|l|}{ Exposure Factor } \\
\hline Heterosexual & 64 & 44 & 7 & 3 & 4 & 4 & 2 \\
\hline Homo/Bisexual & 28 & 23 & 1 & - & 1 & 2 & 1 \\
\hline IVDU & 8 & 6 & 1 & - & 1 & - & - \\
\hline \multicolumn{8}{|l|}{ CD4 T cell counts } \\
\hline$<200$ cells $/ \mu 1$ & 32 & 24 & 2 & 1 & 2 & 2 & 1 \\
\hline $200-499$ cells $/ \mu 1$ & 38 & 25 & 6 & 2 & 2 & 2 & 1 \\
\hline$>499$ cells $/ \mu 1$ & 30 & 24 & 1 & - & 2 & 2 & 1 \\
\hline \multicolumn{8}{|l|}{ Age } \\
\hline 20-29 & 29 & 16 & 5 & 1 & 1 & 3 & 3 \\
\hline $30-39$ & 39 & 30 & 3 & 1 & 3 & 2 & - \\
\hline $40-49$ & 23 & 19 & 1 & 1 & 2 & - & - \\
\hline$>50$ & 9 & 8 & - & - & - & 1 & - \\
\hline
\end{tabular}

IVDU: intra-venous drug user; ND: not determined.

in our study. Previous studies using the same methodological approach found B" subtype frequencies ranging from 30 to $57 \%$, depending on the geographic origin of the studied population (Covas et al. 1998, Morgado et al. 1998a, Gadelha et al. 2003). As before, no associations between B" and the different patient exposure categories were found.

Although the importance of the Brazilian subtype B in the AIDS epidemic is not fully understood, its high prevalence could be an important molecular epidemiological parameter of the HIV pandemic and therefore relevant to be monitored for future vaccine development and testing in Brazil.

\section{REFERENCES}

Brazilian Network for the HIV-1 Isolation and Characterization (Bongertz V, Bou-Habib DC, Brígido LFM, Caseiro M, Chequer PJN, Couto-Fernandez JC, Ferreira PC, GalvãoCastro B, Greco D, Guimarães ML, Linhares de Carvalho MI, Morgado MG, Oliveira CAF, Osmanov S, Ramos CA, Rossini M, Sabino E, Tanuri A, Ueda M) 2000. HIV-1 diversity in Brazil: genetic, biologic and immunologic characterization of HIV-1 strains in three potential HIV vaccine evaluation sites. J Acquir Immune Defic Syndr 23: 184-193.

Carr JK, Ávila M, Carrillo MG, Salomon H, Hierholzer J, Watanaveeradej V, Pando MA, Negrete M, Russell KL, Sanchez J, Birx D, Andrade R, Vinoles J, McCutchan FE 2001. Diverse BF recombinants have spread widely since the introduction of HIV-1 into South América. AIDS 15: F41-F47.

Cornelissen M, Kampinga G, Zorgdrager F, Goudsmit J, the UNAIDS Network for HIV Isolation and Characterization
1996. Human immunodeficiency virus type 1 subtypes defined by env show high frequency of recombinant gag genes. J Virol 70: 8209-8212.

Couto-Fernandez JC, Eyer-Silva WA, Guimarães ML, ChequerFernandez SL, Grinsztejn B, Delaporte E, Peeters M, Morgado MG 2006. Phylogenetic analysis of Brazilian HIV type 1 subtype D strains: tracing the origin of this subtype in Brazil. AIDS Res Hum Retroviruses 22: 207-211.

Couto-Fernandez JC, Silva-de-Jesus C, Veloso VG, Rachid M, Gracie RSG, Chequer-Fernandez SL, Oliveira SM, ArakakiSanchez D, Chequer PJN, Morgado MG 2005. Human immunodeficiency virus type 1 (HIV-1) genotyping in Rio de Janeiro, Brazil: assessing subtype and drug-resistance associated mutations in HIV-1 infected individuals failing highly active antiretroviral therapy. Mem Inst Oswaldo Cruz 100: 73-78.

Covas DT, Bíscaro TA, Kashima S, Duarte G, Machado AA 1998. High frequency of the GWG (Pro Trp) envelope variant of HIV-1 in Southeast Brazil. J Acquir Immune Defic Syndr Hum Retrov 19: 74-79.

Delwart EL, Shpaer EG, Louwagie J, McCutchan FE, Grez M, Rübsamen-Waigmann H, Mullins JI 1993. Genetic relationships determined by a DNA Heteroduplex Mobility Assay: analysis of HIV-1 env genes. Science 262: 1257-1261.

Gadelha SR, Shindo N, Cruz JNM, Morgado MG, GalvãoCastro B 2003. Molecular epidemiology of human immunodeficiency virus-1 in the state of Ceará, Northeast, Brazil. Mem Inst Oswaldo Cruz 98: 461-464.

Guimarães ML, Bastos FI, Telles PR, Galvão-Castro B, Diaz RS, Bongertz V, Morgado MG 2001. Retrovirus infections in a sample of injecting drug users in Rio de Janeiro city, Brazil: 
prevalence of HIV-1 subtypes, and co-infection with HTLVI/II. J Clin Virol 21: 143-151.

Guimarães ML, dos Santos Moreira A, Loureiro R, Galvão-Castro B, Morgado MG, Brazilian Network for HIV Isolation and Characterization 2002. High frequency of recombinant genomes in HIV type 1 samples from Brazilian southeastern and southern regions. AIDS Res Hum Retroviruses 18: 12611269.

Heyndrickx L, Janssens W, Zekeng L, Musonda R, Anagonou S, Van der Auwera G, Coppens S, Vereecken K, De Witte K, Van Rampelbergh R, Kahindo M, Morison L, McCutchan FE, Carr JK, Albert J, Essex M, Goudsmit J, Asjo B, Salminen M, Buvé A, study group on the heterogeneity of HIV epidemics in African cities and van der Groen G 2000. Simplified strategy for detection of recombinant human immunodeficiency virus type 1 group $\mathrm{M}$ isolates by gag/env heteroduplex mobility assay. J Virol 74:363-370.

Hu DJ, Buvé A, Baggs J, van der Groen G, Dondero TJ 1999. What role does HIV-1 subtype play in transmission and pathogenisis? An epidemiological perspective. AIDS 13: 873-881.

Janini LM, Pieniazek D, Peralta JM, Schechter M, Tanuri A, Vicente AC, De La Torre N, Pieniazek NJ, Luo CC, Kalish ML, Schochetman G, Rayfield MA 1996. Identification of single and dual infections with distinct subtypes of human immunodeficiency virus type 1 by using restriction fragment length polymorphism analysis. Virus Genes 13: 69-81.

Join United Nations Programme on HIV/AIDS. AIDS epidemic update. [Online.] http://www.unaids.org (May 2006, date last access).

McCutchan FE 2000. Understanding the genetic diversity of HIV1. AIDS 14 (Suppl. 3): S31-S44.

Ministério da Saúde 2005. Programa Nacional DST e AIDS. Boletim Epidemiológico AIDS e DST 2005. Ano II, no.1.

Moore JP, Parren PWHI, Burton DR 2001. Genetic subtypes, humoral immunity and human immunodeficiency virus type 1 vaccine development. J Virol 75: 5721-5729.

Morgado MG, Guimarães ML, Galvão-Castro B 2002. HIV-1 polymorphism: a challenge for vaccine development - A Review. Mem Inst Oswaldo Cruz 97: 143-150.

Morgado MG, Guimarães ML, Gripp CBG, Costa CI, Neves Junior I, Veloso VG, Linhares-Carvalho MI, Castello-Branco LR, Bastos FI, Kuiken C, Castilho EA, Galvão-Castro B, Bongertz $\mathrm{V}$, and the Hospital Evandro Chagas AIDS Clinical Research Group 1998b. Molecular epidemiology of HIV-1 in Brazil: high prevalence of HIV-1 subtype B and identification of an HIV-1 subtype D infection in the city of Rio de Janeiro, Brazil. J Acquir Immune Defic Syndr Hum Retrovirol 18: 488494.

Morgado MG, Guimarães ML, Neves Junior I, Veloso VG, Linhares-Carvalho MI, Castello-Branco LR, Bastos FI, Castilho EA, Galvão-Castro B, Bongertz V, and the Hospital Evandro Chagas AIDS Clinical Research Group 1998a. Molecular epidemiology of HIV-1 in Brazil: polymorphism of the antigenically distinct HIV-1 B subtype strains. Mem Inst Oswaldo Cruz 93: 383-386.

Stefani MM, Pereira GA, Martelli CM, Shindo N, Galvão-Castro B 2000. Evidence of HIV-1 genetic diversity among pregnant women with AIDS or infected with HIV-1 in Central Brazil. J Acquir Immune Defic Syndr 23: 205-207.

Turchi MD, Diaz RS, Martelli CMT, Sabino EC, Silva WP, Ferreira Filho O, Laranjeira RR, Busch MP, Castelo A 2002. Genetic diversity and HIV-1 incidence estimation among cocaine users in São Paulo, Brazil. J Acquir Immune Defic Syndr 30: 527-532.

van Harmelen J, Wood R, Lambrick M, Rybicki EP, Williamson AL, Williamson C 1997. An association between HIV-1 subtypes and mode of transmission in Cape Town, South Africa. AIDS 11: 81-87.

Vidal N, Peeters M, Mulanga-Kabeya C, Nzilambi N, Robertson D, Ilunga W, Sema H, Tshimanga K, Bongo B, Delaporte E 2000. Unprecedented degree of human immunodeficiency virus type 1 (HIV-1) group M genetic diversity in the Democratic Republic of Congo suggests that the HIV-1 pandemic originated in Central Africa. J Virol 74: 10498-10507.

Wainberg MA 2004. HIV-1 subtpe distribution and the problem of drug resistance. AIDS 18 (Suppl. 3): S63-68. 